\title{
都市計画教科書のテキスト分析 CONTENT ANALYSIS OF TEXTBOOKS IN URBAN PLANNING
}

\author{
石川 徹* \\ Toru ISHIKAWA
}

\begin{abstract}
This study examined nine major textbooks in urban planning through a text mining approach. 127 important terms were identified from the textbook indexes, and the degrees of similarity between pairs of the terms were computed through the analysis of the pattern of co-occurrence. Based on this similarity measure, the important terms were classified into four groups, each explaining (a) basic concepts and methods of urban planning; (b) the development of urban and residential environments, particularly new towns; (c) the maintenance and assessment of residential environments; and (d) connections to other related domains such as laws and regulations, economic frameworks, national land planning, or planning history. In textbooks published after the year 2000, these terms were explained in a more interrelated manner, especially in the context of detailed micro-level planning and in relation to the concepts of diversities, urban restoration, public participation, and city shrinkage, which reflect recent societal trends.
\end{abstract}

Keywords: Urban planning education, Urban planning as a discipline, Textbooks, Text Analysis, Term co-occurrence, Similarity 都市計画教育, 都市計画学, 教科書, テキスト分析, 共起関係, 類似度

\section{1. はじめに}

ヨーロッパの産業革命期に、都市部への人口集中と環境覀化に対 応すべく誕生したとされる近代都市計画であるが、その後現在に至 るまで、様々な実践面での取り組みがおこなわれてきたとともに、 ハワードによる田園都市構想やペリーによる近隣住区論をはじめ、 多くの理念・考え方も提唱されてきた 1 。

このように都市計画の取り組みが進展するにつれ、学問分野とし ての都市計画も、とくに 1960 年代以降広く知られるようになり、 大学等の教育機関において専門的な教育・研究がおこなわれるよう になってから半世紀ほどの歳月が過ぎた ${ }^{2}$ 。

都市計画学については、その現状や可能性に関して様々な議論が あるものの ${ }^{3)}$ 、都市計画に関する学科・専攻・コースを置く教育機 関や都市計画に関寸る専門書・一般書が相当数見られることからも、 学問分野としての都市計画は一定の社会的認知を得られていると想 像される。

さらに最近では、少子高齢化および低炭素社会志向に伴い、拡大 を背景とした「規制」のための都市計画から、縮小時代に対応した 「誘導」のための都市計画への転換も叫ばれている4)、5)。こういっ た新しい動きに対応できるような都市計画の理念も現在求められて いると言える。

このような中、今後の都市計画を展望する上でも、組織的な開始 からおよそ 50 年が経った都市計画学の現状を整理することは有意 義だと思われる。そのための方法の一つとして、現在の都市計画教
育において広く一般に利用されている教科書の内容を分析し、学問 としての都市計画を構成する要素を抽出し整理することが考えられ る。

これは、広くはテキストマイニングと呼ばれる方法であり、文章 中に現れる語句の頻度や関係性を見ることで、対象テキストの内容 を分析しようとするものである ${ }^{6}$ 。 最近では、書籍をスキャナなど を用いて電子ファイル化することができ、コンピュータでの分析も 可能になったため、このようなテキスト分析は盛んにおこなわれて いる。各分野の教科書の内容分析も最近よく見られ、都市計画に関 連する分野では、地理情報科学の教科書分析 7) や住宅建設計画・答 申のテキスト分析 8 ) などある。

そこで、本研究は、おもに建築・都市分野における都市計画教科 書を対象に内容の分析をおこない、都市計画を教える上で重要と考 えられている項目を抽出および整理し、学問としての都市計画の現 状や時代的変化を考察することを目的とする。

\section{2. 方法}

\section{(1) 対象とした都市計画教科書}

本研究では、都市計画の代表的な教科書として、大学での講義あ るいは一般向けの書籍案内などで利用・紹介されることの多い以下 の 9 冊を取り上げた。

(1)『都市計画（第 3 版）』，日笠端・日端康雄，共立出版，2008（初 版 1977 ; 第 2 版 1986)

\footnotetext{
* 東京大学空間情報科学研究センター 准教授 $\cdot \mathrm{Ph} . \mathrm{D}$. 
(2)『都市計画 (第 2 版)』, 土井幸平 $\cdot 川 上$ 秀光・森村道美・松本 敏行, 彰国社, 1997（初版 1981）

(3)『市街地整備計画』, 土田旭 - 伊丹勝 - 日端康雄 - 内田雄造 - 林 泰義・高見澤邦郎，彰国社，1984

(4)『住宅地計画』, 土肥博至 - 御舩哲, 彰国社, 1985

(5)『都市計画教科書 (第 3 版)』, 都市計画教育研究会編, 彰国社, 2009（初版 1987）

(6)『住環境を整備する』, 住環境の計画編集委員会編, 彰国社, 1991

(7)『初学者のための都市工学入門』, 高見沢実, 鹿島出版会, 2000

(8)『新・都市計画総論』, 佐藤圭二・杉野尚夫, 鹿島出版会, 2003

(9)『初めて学ぶ都市計画』, 饗庭伸・他, 市厅谷出版社, 2008

これら 9 冊の教科書は、1970 年代に初版が発行され都市計画教 育の初期から親しまれているものから、ごく最近発行された新しい ものまで広く含んでおり、もちろんすべての教科書を網羅している とは言わないものの、建築・都市分野で一般的に名前が挙がる代表 的なものは含まれていると考え、選定した（たとえば文献 9 などを 参照)。

\section{(2) テキストデータの準備}

上記の各教科書をスキャナでコンピュータに取り込み、OCR ソフ 卜を用いて文字認識をした後、文字や段落などの細かな体裁を整え、 分析の対象となるテキストデータを準備した。

\section{(3) 重要語の選定}

テキストの内容分析をするに当たっては、文章中に現れる重要な 語句を抽出し、その相互関係を調べることが代表的な方法として挙 げられる。本研究でもこの方法を用いるが、そのためには、分析の 対象として着目すべき語句、寸なわち「重要語」の選出をしなけれ ばならない 10)。本研究では、地理情報科学の教科書分析 7)において 用いられた手法を参考にし、教科書末尾の索引に掲載された語句(す なわち、著者が重要な概念として選定した語句）を利用した。

前述の 9 冊の教科書のうち、索引が付属していない 1 冊を除く計 8 冊の索引にまとめられている語句を調べたところ、半数である 4 冊以上の索引に出てくる語句は 53 語あった（表 1 )。

表 1 半数以上の教科書索引に出てくる語句 (50 音順)

街区、開発許可制度、開発行為、環境影響評価、幹線道路、 換地、既成市街地、近代都市計画、近隣公園、区画道路、建 築基準法、建築協定、建築線、建ぺい率、耕地整理、公聴会、 コミュニティ、市街化区域、市街化調整区域、市街地開発事 業、市街地建築物法、市街地再開発事業、住宅地区改良事業、 準工業地域、人口集中地区（DID）、線引き、千里ニュータウ ン、大ロンドン計画、地域地区、地区計画、地区計画制度、 地区整備計画、東京市区改正条例、同潤会、田園都市、都市 計画区域、都市計画事業、都市計画法、都市公園法、都市再 開発法、都市施設、都市総合計画、土地区画整理、土地利用、 土地利用計画、日照条件、ニュータウン、不良住宅地区改良 法、マスタープラン、容積率、用途地域、ラドバーン、隣棟 間隔
これら 53 語に加えて、 8 冊中 3 冊の索引に出てくる語句 74 語も 含め、合計 127 語を今回分析する重要語とした。この 74 語を加え た理由は、表 1 の 53 語だけでは数がまだ少なく（8 冊の索引に現れ る語句全体の $2 \%) 、 一$ 方で、 8 冊中 2 冊の索引に出てくる語句 $(318$ 語）まで加えると数が多くなり過ぎる点を考慮したためである。

\section{(4) 重要語相互の関係性の分析}

つぎに、前節で選んだ重要語が、9 冊の教科書においてどのよう に説明されているかを調べるために、各重要語の組（ペア）が同時 に出現する回数（共起回数）を分析した。これは、互いに関係性が 強い（概念的に意味が近い）語句ほど文章中で近い位置に現れるで あろうという考え方に基づくものである。

ところで、語句の組が「同時に出現する」という現象を考えるた めは、どの範囲内で出現した場合に「同時」と判断するかを決める ことが必要となる。この「範囲」(分析単位) としては、大きなもの (本全体、章) から小さなもの（段落、文）まで考えられるが、あ まりに大きい範囲で見た場合には同時という意味が薄れ、一方あま りに小さい範囲で見た場合にはすべての語句が独立に出現するとい う判断になってしまう。そこで本研究では、意味の一まとまりとし て「段落」に着目し、同一の段落内で二語が現れた場合は「同時に 出現した」と判断することにした。

また、「同時に出現する回数」についても、大きく二つの考え方が できる。一つは、ある 2 つの語句が同時に現れる回数が多い程その 2 つの語句の関係が強いとみな寸考え方である。もう一つは、ある 2 つの語句がそれ以外の他の語句と同時に現れる回数をそれぞれ調 べ、その分布が似ている程その 2 つ語句も似ているとみな寸考え 方である。前者の方法を用いた場合には総出現段落数が多い語句間 で類似度が高くなる傾向が強いが、後者の方法を用いることで、単 に出現回数だけではなく、語句間の結び付きを考慮した分析が可能 になる 7)。よって、本研究でも後者の方法を用いる。

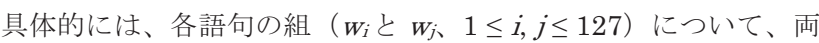
者が同一段落中に現れる回数を各語の平均出現率で規準化した值を 求めることにより、語句間の共起行列を算出し、第 $i$ 行ベクトルと 第 $j$ 行ベクトル間のユークリッド距離（ただし、類似度を求める対 象の二語の共起は計算に含めない）をもって、語句 $w_{i}$ と $w_{j}$ の類似 度を示す指標とする（詳細は文献 7、p. 132 を参照）。なおこれらの 作業に際しては、Java および Perl 言語によるプログラミングをお こなった。

\section{3. 重要語間の類似度の分析}

前節で述べた方法で得られた類似度に基づき重要語を分析するた め、まず多次元尺度構成法 (MDS) を用いて語句の分類をおこなった。 MDS 解（布置）の指標であるストレスの值は 0.1 以下のときにその 当てはまりが良いとされ ${ }^{11)}$ 、これに従い、本研究では 6 次元の解を 抽出した。

つぎに、この 6 次元での布置において、似ている語句（互いに近 い距離にある語句）を調べるため、6 次元解をクラスター分析し、 詳細な分類をおこなった。その結果、127 個の重要語を以下のよう な四つのグループ（表 2、各グループ 50 音順）に分けられることが わかった（クラスター分析のデンドログラムを図 1 に示す）注1)。 
表 2 類似度に基づく重要語の四グループへの分類（下線は より代表的と考えられる語句；4 章および図 2 参照）

【グループ 1】

〔サブグループ 1]アイデンティティ、インフラストラクチュア、 街区、開発許可制度、開発行為、画地、幹線道路、既成市街地、 区域区分、下水道、建築基準法、建築線、コミュニティ、市街 化区域、市街化調整区域、市街地開発事業、市街地建築物法、 市街地再開発事業、城下町、人口集中地区（DID）、スプロール 市街地、生活圈、線引き、総合計画、宅地開発指導要綱、地域 地区、地区計画、地区詳細計画、田園都市、道路構造令、都市 基本計画、都市計画、都市公園法、都市更新、都市構造、都市 再開発、都市施設、土地利用、土地利用計画、パリ、分布交通 量、マスタープラン、用途地域

〔サブグループ 2]近隣商業地域、区画道路、形態規制、建ぺい 率、工業専用地域、準工業地域、準住居地域、容積率

〔サブグループ 3] 建築協定、再開発地区計画、集団規定、集落 地区計画、総合設計制度、地区計画制度、地区整備計画、風致 地区、防火規制、まちづくり条例

〔サブグループ 4]換地、減歩、耕地整理、住宅地区改良事業、 新住宅市街地開発事業、土地区画整理、日本住宅公団、三ュー タウン

〔サブグループ 5]都市再開発法、日照条件、防災建築街区造成 法、隣棟間隔

〔サブグループ 6]パーソントリップ調査、緑のマスタープラン 【グループ 2】

運動公園、衛星都市、近隣公園、近隣住区、近隣住区論、高蔵 寺ニュータウン、児童公園、焦区、住区基幹公園、千里ニュー タウン、総合公園、大ロンドン計画、地区公園、都市基幹公園、 ブキャナン・レポート、ラドバーン、レッチワース

\section{【グループ3】}

安全性、快適性、住宅営団、主要幹線道路、同潤会、バリアフ リ一、不良住宅地区改良法、保健性、ライフライン、利便性

$$
\text { 【グループ 4】 }
$$

CIAM、アテネ憲章、環境影響評価、近代都市計画、公聴会、国 土総合開発法、産業革命、受益者負担金、上位計画、進化する 都市、スーパー堤防、地方債、東京市区改正条例、特別都市計 画法、都市計画区域、都市計画事業、都市計画制限、都市計画 法、都市高速鉄道、都市総合計画、プランナー、法定都市計画

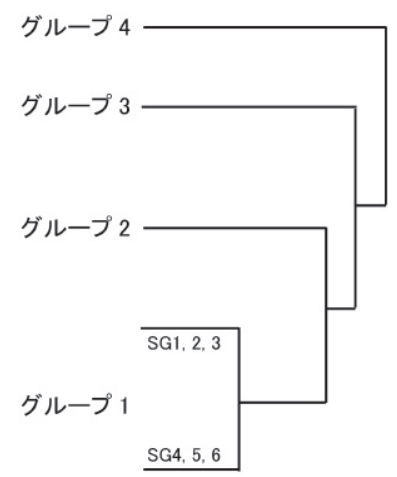

図 1 クラスター分析結果の模式図 (SG : サブグループ)
表 2 から、まずグループ 1 は、都市計画の基本的な概念を説明す る語を網羅していることがわかる。本グループに属する語句は他の グループと比べて多いことから、さらに詳しく分析するため、グル 一プ内をさらに詳細に見ると、二つの小グループに分かれ、それぞ れがさらに三つずつの小グループ（以下サブグループと呼ぶ）に分 かれた。

サブグループ 1〜3 が一つの小グループを形成し、それぞれ、都市 計画の背景、歴史、基本概念や制度などを説明する語句、都市計画 における代表的な手法である用途地域制を説明する語句、詳細なミ クロスケールの計画である地区計画制度や建築協定・条例などにつ いて説明する語句からなる。

また、サブグループ 4 〜 6 がもう一つの小グループを形成し、それ ぞれ、土地区画整理、都市再開発、具体的な調査・計画法を説明す る語句からなる。

グループ 2 は、具体的に住宅地を計画する際に必要となる計画概 念や構成要素、および実際の計画例に関する語句からなる。これら は、グループ 1 の基本概念や手法を応用展開した市街地・住宅地開 発に関する語句であり、とくに我が国の都市計画の歴史において重 要な役割を担ったニュータウンを実例に説明がされている。

グループ 3 は、前述の二つのグループから一つ上位のクラスター を形成し、住環境整備系の用語からなり、住宅地の計画を立案・実 施・評価する際に考慮す心゙き指標が見られる。また、それらの指標 を説明する具体的計画として、都市計画初期の取り組みを代表する 事例 (同潤会、住宅営団、不良住宅地区改良法) が挙げられている。

グループ 4 は、上記三つのグループからさらに上位のクラスター を形成しており、より広域な視点から都市計画を説明する語句から なる。具体的には、日本全国を対象とした国土計画、都市計画に関 連する法制度、開発に関連する経済的な枠組み、近代都市計画の歴 史などが含まれる。

これら四つのグループを見ると、都市計画という分野を学問的に 教えるに当たって、その理念・法体系・各種規制手法などの基本概 念、実際の市街地・住宅地開発への応用、住環境の整備、さらにそ れらを周辺分野との関連から議論する包括的な視点の四つが重要な 要素となっていることがわかる注2)。

\section{4. 教科書の年代比較}

続いて、上記で得られた全体的傾向を年代的に見るため、今回取 り上げた 9 冊の教科書を、西暦 2000 年より前に出版されたもの (2-(1)節の(2),(3),(4),(6)）とそれ以降に出版されたもの（2-(1)節の(1), (5),(7),8,(9)）の大きく二つに分け、これらにおいて重要語が現れる 様子を比較した（なお改訂版が出ている教科書については最新版の 出版年を用いた)。

両年代の教科書について、表 2 でまとめた四グループの重要語の 位置関係を平面上で見るため、それぞれについて 2 次元での MDS 布置を示すと図 2 のようになった。この図から、2000 年以降の教 科書では、四つの重要語グループがそれぞれ大きく二つ（図 2 下図 の左下のグループ $\mathrm{A}$ と右上のグループ B）に隔てられていることが わかる注 3 )。 


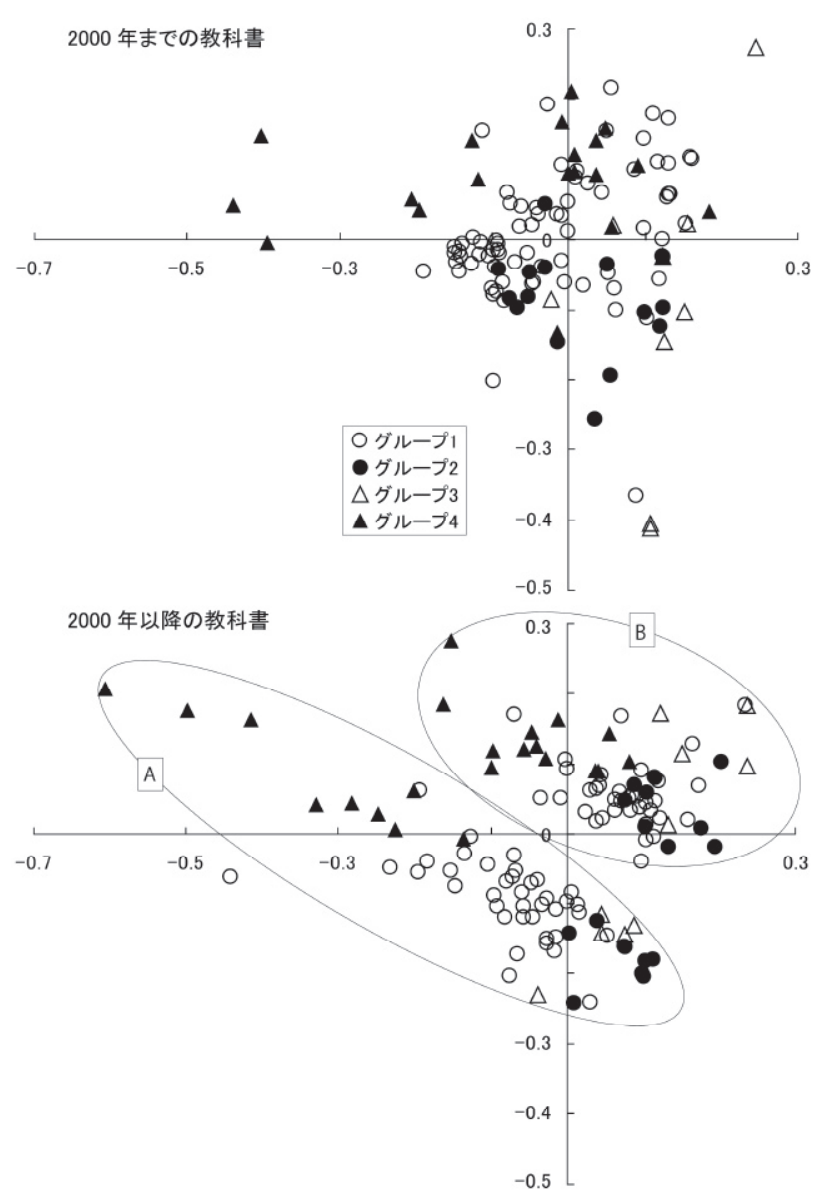

図 2 重要語の 2 次元布置の年代比較 (グループ 1〜 4 は表 2 の重要語グループに対応)

2000 年以降の教科書におけるこの二グループ (A と B ) を詳しく 比較すると、語の代表度と類似度に差があることがわかった（グル ープ A に属する語句は、表 2 において下線で示した)。まず語の代 表度については、半数 (8 冊中 4 冊) 以上の教科書索引に出てくる 語句（表 1）と 8 冊中 3 冊の索引に出てくる語句の比が、グループ A では 34:25、グループ B では 19:46 であり、グループ A の方がよ り多くの教科書索引に掲載されている語句からなる（比率の差は力 イ二乗検定で $1 \%$ 有意)。

語句間の類似度（2-(4)節で求めた值）については、その平均がグ ループ A では 0.57、グループ B では 0.51 であり、グループ A の方 が互いに関係性が強い語句からなる。また、2000 年までの教科書に おける平均類似度は 0.46 であり、最近の教科書ほど各重要語が同一 の段落中で相互に関係付けられて説明されていることがわかる（平 均の差は $t$ 検定で $0.1 \%$ 有意)。

さらに、図 2 における語句の位置のばらつき（分布の平均中心点 からの距離の 2 次元的標準偏差）を、2000 年までと 2000 年以降の 教科書で比較すると、グループ 2 では值が大きくなり（0.11 から 0.13 )、グループ 3 では值が小さくなっていた $(0.20$ から 0.16 一)。 すなわち、最近の教科書においては、ニュータウン計画に関する語 句は相互の結び付きが弱まっているのに対して、住環境整備に関す る語句は結び付きが強くなっている。

これらの結果は、最近の教科書では、各語句が互いに関連付けら
れて説明され、より重要と考えられる語句とそれらを補助する役割 の語句が分化される傾向にあることを示している。年代とともに、 都市計画学についてある種の共通した見方が形成されてきたとも考 えられ、それらいわゆる中核をな寸語句が表 2 の下線部であると言 える。

\section{5. 重要語間の関係の分析}

本章では、前章までの教科書の分析に引き続き、重要語相互の関 係をより詳しく見るため、2000 年までの教科書および 2000 年以降 の教科書において、とくに類似度が高い語句の組を調べた（表 3)。 なお、ここでは、2-(4)節で述べた類似度指標である距離が、全体の 平均から標準偏差の 2.5 倍以上離れて短いものを、とくに類似度が 高い語句の組として扱った。

\section{表 3 類似度が高い重要語の組}

\section{【2000 年までの教科書】}

(1) 土地利用、土地利用計画

（2）市街地開発事業、都市基本計画、都市計画制限、法定都市 計画

（3）パーソントリップ調查、物資流動調查

\section{【2000 年以降の教科書】}

（1）土地利用、土地利用計画

（2）近代都市計画、建築基準法、市街地開発事業、宅地開発指 導要綱、地域地区、都市基本計画、都市計画、都市計画事業、 都市計画法、分布交通量、法定都市計画、マスタープラン

（3）インフラストラクチュア、運動公園、児童公園、集団規定、 進化する都市、総合公園、宅地開発指導要綱、地区詳細計画、 都市計画、都市更新、日照条件、パーソントリップ調查、物資 流動調查、分布交通量、防火規制、まちづくり条例

（4）市街化区域、市街化調整区域、線引き

（5）運動公園、住区基幹公園、総合公園、地区公園、都市基幹 公園、分布交通量

(6) 近隣住区、近隣住区論、住区

（7）開発許可制度、開発行為

（8）住宅営団、住宅地区改良事業、同潤会

（9）受益者負担金、地方債

これを見ると、結び付きの強い重要語のグループ数・語句数が増 えており、前章で示したように、2000 年以降の教科書の方が各重要 語をより密接に関連付けて説明していることがわかる。とくに、都 市計画と各種法制度・事業制度との関連付け（表 3 の項目(2)）や、 種々の都市計画調查、都市の構成要素、住環境条件、地区詳細計画 やまちづくり条例などの詳細計画の関連付け（表 3 の項目(3)）が強 くなっている。

さらに、今回分析の対象とした 9 冊の教科書に出現した頻度がと くに高かった重要語（都市計画、土地利用、ニュータウン、コミュ ニティ、地区計画、都市計画法、街区、住区、土地区画整理）につ いて、それぞれと類似度が高い語句上位 10 語を、2000 年までと 2000 年以降の教科書で比較したところ、コミュニティ、地区計画、 街区、住区の 4 語について、特徴的な違いが現れた（表 4、それぞ 
れ結び付きの強い順)。

最近の教科書では、上記の 4 語が相互に関連付けられ、生活圈な どを意識しながら、建築協定やまちづくり条例などミクロな詳細計 画の文脈で説明されていることがわかる。また、フローに対するス トックの時代という社会的背景も反映し、コミュニティや街区の概 念が既成市街地との結び付きで説明されている。その一方で、ブキ ヤナン・レポートなどは、ある種都市計画の古典の位置を占めるよ うになり、最近の教科書では他の語句と強い関連を持たない傾向に あることもわかる。

表 4 高頻出の重要語と結び付きが強い語句

\begin{tabular}{|c|c|}
\hline 【2000 年までの教科書】 & 【2000 年以降の教科書】 \\
\hline 〔コミュニティ一〕 幹線道路、 & [コミュニティー] ニュータ \\
\hline 都市計画、都市施設、住区、都 & ウン、住区、幹線道路、都市 \\
\hline 市基本計画、環境影響評価、ス & 計画、近隣住区、近隣住区論、 \\
\hline 一パー堤防、バリアフリー、ブ & 生活圏、分布交通量、地区計 \\
\hline キャナン・レポート、主要幹線 & 画、既成市街地 \\
\hline 道路 & \\
\hline 〔地区計画一〕地区計画制度、 & 〔地区計画一〕都市計画、地 \\
\hline 都市計画、建築協定、都市施設、 & 区計画制度、建築協定、地域 \\
\hline 都市計画法、法定都市計画、用 & 地区、建築基準法、用途地域、 \\
\hline 途地域、市街地開発事業、地域 & 市街地開発事業、土地利用、 \\
\hline 地区、都市基本計画 & まちづくり条例、街区 \\
\hline 〔街区一〕都市施設、画地、都 & 〔街区一〕都市計画、地域地 \\
\hline 市計画、幹線道路、 & 区、分布交通量、まちづくり \\
\hline イ、環境影響評価、フ & 条例、地区計画、建築基淮法、 \\
\hline 防、バリアフリー、ブキ & 宅地開発指導要綱、土地利用、 \\
\hline ン・レポート、主要幹線道路 & 市街地開発事業、既成市街地 \\
\hline 〔住区一〕近隣住区、近隣住区 & 〔住区一] 近隣住区、近隣住 \\
\hline 論、コミュニティ、幹線道路、 & 区論、ニュータウン、コミュ \\
\hline ラドバーン、都市計画、都市基 & ニティ、ラドバーン、生活圈、 \\
\hline 本計画、衛星都市、都市施設、 & 近隣公園、分布交通量、千里 \\
\hline 環境影響評価 & ニュータウン、幹線道路 \\
\hline
\end{tabular}

\section{6. 近年の計画動向・社会動向を表す語句との関係の分析}

前章まででは、テキスト中に現れる語句およびその相互関係に着 目して教科書を分析したが、本章では、より広い視点・社会的な観 点から分析するため、近年の都市計画動向や社会の動向を表す語句 を選定し、それらが先に分析した重要語とどのような関係で説明・ 記述されているかを見る。

そのために、今後の都市計画像などいわゆる新しい都市計画につ いて書かれた最近の本 3)、12) に出てくる語句、および多様・縮小な ど最近一般に注目を集めていると思われる語句を参考に、91の語句 を選定した注4)。その中で、今回対象とした教科書において計 10 段 落以上に出現する語句（住環境、再編、ダイナミック、多様、高齢 者、景観条例、災害、高齢化、愛着、ネットワーク、縮小、高度化、 再生、人口減少、特定街区、住民参加、市民参加、ユニバーサルデ ザイン、ストック、バリアフリー、情報化、地図、コンピュータ、 中心市街地活性化）注 5) について、前章と同様に類似度が高い語句
の組を調べたところ、表 5 （それぞれ結び付きの強い順）のように なった。

表 5 計画・社会動向を表寸語句と結び付きが強い語句

\begin{tabular}{|l|l|}
\hline 〔住環境—〕多様 & 【2000 年までの教科書】 \\
\hline & 【2000 年以降の教科書】
\end{tabular}

〔住環境一〕コミュティ、ニュータウン、マスタープラン、 街区、幹線道路、既成市街地、建築基準法、地域地区、地区計 画、都市施設、土地利用、用途地域、生活圈、都市計画、分布 交通量、多様、災害、ネットワーク、再生、住民参加、地図 [多様一〕マスタープラン、開発行為、街区、幹線道路、既成 市街地、建築基準法、市街地開発事業、地域地区、地区計画、 都市施設、土地利用、用途地域、パリ、下水道、生活圈、総合 計画、都市基本計画、都市計画、都市構造、住環境、災害、再 生、住民参加、地図

〔再生一〕マスタープラン、街区、既成市街地、市街地開発事 業、地域地区、地区計画、都市施設、用途地域、生活圈、都市 計画、住環境、多様、災害、住民参加、再編、縮小

〔住民参加一〕コミュニティ、マスタープラン、街区、既成市 街地、地域地区、地区計画、都市施設、用途地域、生活圈、都 市計画、住環境、多様、災害、再生

〔地図一〕マスタープラン、開発行為、街区、既成市街地、市 街化区域、市街地開発事業、線引き、地域地区、地区計画、都 市施設、土地利用、用途地域、都市基本計画、都市計画、住環 境、多様、災害

〔再編一〕既成市街地、再生

〔縮小一〕街区、既成市街地、災害、再生

〔市民参加一〕マスタープラン

2000 年までの教科書ではこれらの語句と結び付きが強い語句は 見られないのに対し、2000 年以降の教科書では大幅に数が増えてい る。とくに、住環境、多様、再生、住民参加といった語句が相互に 結び付き、街区、地区計画、コミュニティ、生活圈といったミクロ レベルでの住環境整備に関係する語句と関連付けられていることが わかる。

また、縮小、再編、既成市街地、再生の結び付き、および住民参 加、市民参加、マスタープランの結び付きも強い。これらには、都 市計画における最近の強い問題意識が現れている。

地図については、マスタープラン、線引き、地域地区、土地利用、 都市基本計画などとの結び付きから、都市計画の様々な局面で地図 が利用されていることがわかるが、それに加えて、災害との関係性 も強く、都市の基本的情報として地図（場所情報）が担う大きな役 割を示している。

なお、災害については、他の多くの語句とも結び付きが強くなっ ているが、これは、とくに阪神・淡路大震災以降、防災都市づくり や安全・安心を目指した市街地整備計画の重要性が認識され、都市 計画と防災が関連付けられて議論されることが多くなっていること の表れとも考えられる。 


\section{7. おわりに}

本研究では、建築・都市分野の代表的な都市計画教科書をテキス ト分析することにより、学問分野としての都市計画について考察を おこなった。分析結果から、都市計画を教えるに当たって重要と考 えられている概念は、大きく四つのグループに分けられることがわ かった。

一つのグループは都市計画の基本的概念についての語群であり、 都市計画の歴史や背景、マクロな土地利用規制である用途地域制、 ミクロなスケールでの地区計画や建築協定、また区画整理や再開発 などが、都市計画の基本かつ重要な構成要素と認識されていること がわかる。

もう一つのグループは、上記グループの概念の応用展開として、 ニュータウンを代表とする具体的な市街地・住宅地開発に関する語 群である。

あと二つのグループは上記の二グループをより高い位置から包括 的に見る概念についての語群であり、安全性や快適性など住環境整 備系の用語と、国土計画や法的・経済的枠組みなど広い視点や他分 野との関係から都市計画を扱う語群である。

これら都市計画を構成する重要概念については、折りに触れて 様々な文脈で確認されてきているとも言えるが、一方で、そのよう な個々の研究者や実務家の間で意識されてきた概念を、客観的に示 した取り組みは、今回が初めてに近いと言える。テキスト分析とい う方法を都市計画教育分野一応用し、多様な教科書を統一的に見る ことを可能にする結果が得られたことは意義深い。

年代的な比較では、2000 年以降に出版された教科書においては、 これらの重要語がより関連付けられた形で説明されていることがわ かった。また、都市計画と社会の関係という視点からは、近年の計 画・社会動向を表す語句との関係の分析から、都市計画においても、 環境、多様、再生、縮小といった概念がとくに最近重要と考えられ ていることが示された。また、一般的に注目を集めているものの、 今回の分析対象とした教科書には多く出てこなかった語句（サステ イナビリティ、情報化など）について考察をおこなうことは、今後 の社会状況に対応した都市計画を展望するに当たって重要な示唆を 与えると考えられる。

最後に、今後の課題として、考察の対象とする教科書を増やして いくことで分析をより精緻なものとすることや、語の出現頻度や共 起回数以外の情報（文脈などの意味的要素）を取り入れた分析をお こなうことが挙げられる。

\section{謝辞}

2 名の匿名差読者の方々から、本論文の内容向上のために建設的 かつ有意義なご意見をいただきました。また、東京大学・浅見泰司 教授からは研究遂行に当たって貴重なご助言をいただき、宮城大 学・高橋信人助教、東京大学・温文氏、高橋一紀氏、武宮誠氏から はプログラミングへのご協力をいただきました。ここに記して謝意 を表します。

\section{参考文献}

1）レオナルド・ベネーヴオロ：近代都市計画の起源，鹿島出版会， 1976

2）高見沢実 : 都市計画・都市計画理論の蓄積をどうとらえるか，都市計画,
Vol. 15 , No. 2, pp. $14-17,2010.4$

3）高見沢実・編著 : 都市計画の理論, 学芸出版社, 2006

4）国土交通省国土技術政策総合研究所 : 市街地における建物形態の性能基準 に関寸る基礎的研究，国土技術政策総合研究所資料，No. 443，2008.1

5）中山徹：人口減少時代のまちづくり，自治体研究社，2010

6) Weiss, S. M., Indurkhya, N., Zhang, T., and Damerau, F. J.: Text mining, New York, Springer, 2005

7）高橋信人，岡部篤行：英文 GIS 教科書における語の共起関係に基づいた 語句の分類, GIS一理論と応用, Vol. 15, pp. 129-136, 2007.12

8）崔廷敏，浅見泰司：言語統計分析による住宅建設五箇年計画及び答申の特 性分析, 日本建築学会計画系論文集, No. 579, pp. 89-96, 2004.5

9）大江守之：住について考えるための基本図書 11一都市計画の本，すまい ろん, No. 49, pp. 52-54, 1999.1

10）松尾豊，石塚満：語の共起の統計情報に基づく文書からのキーワード抽 出アルゴリズム, 人工知能学会論文誌, Vol. 17, No. 3a, pp. 1-7, 2002.5 11) Kruskal, J. B.: Multidimensional scaling by optimizing goodness of fit to a nonmetric hypothesis, Psychometrika, Vol. 29, pp. 1-27, 1964.3 12) 小林重敬 : 都市計画はどう変わるか, 学芸出版社, 2008

\section{注}

注 1）一般的に、クラスター分析で分類数をいくつにするかについては、あ る程度の恣意性が入ることは否めないが、教科書の大きな特徵を議論する に当たり、分類が過度に細かくならず、かつ適度なまとまりを持つように、 ここでは四つのグループ数での説明を試みた。また、127 語のうち、単独 でクラスターを形成し、意味付けも難しいと判断した 3 語（合流式、分流 式、物資流動調査）は以下の分析から除外した。

注 2) 今回分析の対象とした教科書のうち、(4)と(6)住環境に特化しており、 重要語のグループ分けに影響を与えた可能性もある。そのため、この 2 冊 を除外した計 7 冊の教科書に対して分類をおこなったところ、表 2 と同様 の四グループが得られた。分類が一致した語句の割合は、グループ 1 が $80 \%$ (75 語中 60 語)、グループ 2 が 88\%（17 語中 15 語）、グループ 3 が $80 \%$ (10 語中 8 語)、グループ 4 が $91 \%$ （22 語中 20 語）であった。

注 3) 重要語の四グループへの分類に際しては、6 次元 MDS 解を用いたため、 2 次元布置ではそれほど明確なグループ分けが見られないことを注記する。 なお、初版の出版年を用いて 2000 年の前後で比較をおこなった場合にも、 図 2 と同様の結果が得られることを確認した。

注 4）具体的には、文献 3 の巻末資料（「都市計画理論の近年の動向」）およ び文献 12 の索引に含まれる語句から 52 語句を抽出し、その他、情報化、 少子高齢化、バリアフリー、ユニバーサルデザイン、地域コミュニティな どに関連する 39 語句を追加した。後者の選定には筆者の主観が含まれてい る可能性は否定できず、この点については今後の課題としたい。

注 5）近年の計画動向・社会動向を表す他の語句のうち、出現段落数が 9 以 下だった語句は以下のとおり：〔段落数 9]景観地区、効率化、参加型；〔段 落数 7]インセンティブ、非常時; [段落数 6]開発権移転、景観協定、コ ンパクトシティ；〔段落数 5]インターネット、生活の質（QOL）、ハート ビル法、パタン・ラングージ; [段落数 4]少子化、成長管理、都市再生特 別措置法、ライフスタイル；[段落数 3] まちづくり三法、容積移転、TDR ; 〔段落数 2〕グローバル化、景観協議会、郊外居住、集約型、まちなか; 〔段 落数 1] エッジ・シティ、屋外広告物法、持続可能性、少子高齢、ステー クホルダー、スマート・グロース、セキュリティ、地域活動、地理情報シ ステム（GIS）、都心居住；〔段落数 0〕位置（場所）情報、インフィル、 エリアマネジメント、街区再編、環境都市、空間情報、権限分担、子育て 支援、サステイナビリティ、サステイナブル、市街地縮減、住生活基本法、 住情報、住宅品質、循環型、ソーシャル・キャピタル (社会関係資本)、地 域参加、長期優良住宅、電子化、特定容積率、ナビゲーション、200 年住 宅、ユビキタス、立体用途規制、履歴情報、ローカル化、ローカル・コミ ユニティ。 